\title{
THE INFLUENCE OF PROFITABILITY AND STRUCTURE OF OWNERSHIP ON COMPANY VALUE WITH DIVIDEND POLICY AS AN INTERVENING VARIABLE
}

\author{
Ulfah Setia Iswara1, Teguh Gunawan Setyabudi² \\ ${ }^{1}$ STIESIA Surabaya \\ E-mail: ulfahsetiaiswara@stiesia.ac.id \\ ${ }^{2}$ STIESIA Surabaya \\ E-mail: teguhgunawan@stiesia.ac.id
}

\begin{abstract}
Abstrak
Penelitian ini bertujuan untuk menguji dan membuktikan secara empiris pengaruh profitabilitas dan struktur kepemilikan terhadap nilai perusahaan dengan kebijakan dividen sebagai variabel intervening. Penelitian ini termasuk penelitian kuantitatif. Penelitian dilakukan pada perusahaan industri barang konsumsi yang terdaftar di Bursa Efek Indonesia pada tahun 2011 sampai tahun 2016. Data dikumpulkan berupa data laporan tahunan perusahaan tahun 2011 sampai dengan tahun 2016. Analisis data dilakukan menggunakan analisis jalur. Hasil penelitian menunjukkan bahwa profitabilitas berpengaruh signifikan positif terhadap kebijakan dividen, sedangkan struktur kepemilikan tidak berpengaruh pada kebijakan dividen. Profitabilitas perusahaan membuat perusahaan membagikan dividen kepada pemegang saham. Variabel profitabilitas and kebijakan dividen terbukti berpengaruh signifikan pada nilai perusahaan, sedangkan struktur kepemilikan tidak berpengaruh pada nilai perusahaan. Perusahaan dengan kemampuan menghasilkan profit dan membagikan dividen mampu menambah nilai perusahaan.
\end{abstract}

Kata Kunci: nilai perusahaan, kebijakan dividen, struktur kepemilikan, profitabilitas.

\begin{abstract}
This study aims to test and empirically prove the effect of profitability and ownership structure on firm value with dividend policy as an intervening variable. This research is a quantitative research. The study was conducted on consumer goods industry companies listed on the Indonesia Stock Exchange in 2011 to 2016. Data were collected in the form of company annual report data from 2011 to 2016. Data analysis was performed using path analysis. The results showed that profitability had a significant positive effect on dividend policy, while the ownership structure had no effect on dividend policy. The company's profitability makes the company distribute dividends to shareholders. The variable profitability and dividend policy are proven to have a significant effect on firm value, whereas ownership structure has no effect on firm value. Companies with the ability to make profits and distribute dividends can add value to the company
\end{abstract}

Keywords: company value, dividend policy, ownership structure, profitability. 


\section{Introduction}

Lately, with increasing competition, companies need to have careful planning and good management. Management is expected to be able to produce strategic decisions that encourage the achievement of long-term corporate goals. According to Sondang (2005) long-term goals must meet the following criteria: a. Acceptability, b. Flexibility, c. Can be measured, d. Being a driver for satisfactory performance improvement, e. Conformity, f. Can be understood, g. Can be achieved. In the decision-making process, managers must consider financial and non-financial aspects, and must be supported by a planning guideline that includes the steps needed to achieve company goals. The purpose of the company in general is to seek maximum profit (profit) and increase the value of the company (Mardiyati, et al., 2012). To obtain profits desired by the company, the company management must plan, control, and in decision making must be supported by an analysis that benefits the company. To achieve an increase in company value, it can be seen from the value of the shares of a company. According to Fama and French (1998) that the value of the company is reflected in the price of the company's outstanding shares. High stock prices mean the higher the value of the company and this shows the more prosperous shareholders. Sartono (2010) states that company value is the selling value of an operating company. To measure the size of the company's value, it can be done in various ways, including: using the PBV ratio (price to book value) or Tobin's Q ratio. Mardiyati et al. (2012) uses PBV ratio as a measure of company value. Investors or shareholders as owners (principals) in investing their capital certainly expect to get a high rate of return. Profits in the form of dividends are preferred by investors. Profitability shows the company's ability to make a profit, and this is directly proportional to the company's ability to distribute dividends. Mahendra (2011) states that profitability and dividend policy have a positive and significant influence on firm value. This result is supported by Nofrita (2013), Windasari and Riharjo (2017), Muvidha and Suryono (2017), Hakim and Priantinah (2018), Mutmainah et al. (2019), Dewi and Abundanti (2019) who state that a company's dividend policy can significantly influence the value of a company. The increase in dividends is expected to reduce the agency costs that occur due to conflicts of interest between agents and principals. However, the results of the study by Hardiningsih (2009) prove that dividend policy does not affect company value. Dividend policy is proxied by variables Dividend payout ratio (DPR) partially has no significant effect on value company manufacture which is proxied by PBV (Sukirni, 2012 and Mardiyati et al., 2012).

Jensen and Meckling (1976) in agency theory, explained that principals (owners) delegate authority to agents (management) to manage the company and take important decisions regarding the company. Differences in interests can arise where the principal expects to get increasing welfare, while the agent expects to get an award such as a bonus for the performance achieved. This agency conflict can be minimized by means of insider ownership or insider ownership (Jensen and Meckling, 1976), where managers are given the right to participate in owning a company (given company shares). This will have an impact on changes in the ownership structure in a company. The positive relationship between managerial ownership (ownership structure) and firm value is shown in Fuerst and Kang's (2000), Soliha and Taswan (2002), Hakim and Priantinah (2018), Dewi and Abundanti (2019) studies. The results of Hardiningsih (2009) study show managerial ownership does not affect the value of the company. The results of the study show that managerial ownership is significantly negative effect on firm value (Sukirni, 2012).

Based on previous studies related to company value, there are still many inconsistencies in research results (various research results) that lead to motivation to conduct research related to what factors influence the value of the company. This research was carried out on publicly 
listed companies listed on the Indonesian Stock Exchange and which are members of the consumer goods industry sector in Indonesia. The consumer goods industry was chosen as the sample in this study because the consumer goods industry sector experienced the most significant growth in sectoral indices, this was due to the increasing pattern or consumptive behavior of the Indonesian people, and was expected to reflect the overall value of the company. Bisnis.com in 2019 states the financial performance of the consumer goods industry sector in 2018 is positive. Consumption 2018 also grew 5.05\%, higher than 2017 which amounted to $4.95 \%$. Retail sales growth also rose from $2.9 \%$ in 2017 to $3.7 \%$ in 2018 . This year, the government is targeting an economic growth of $5.2 \%$, so that indicators of consumption spending and retail sales also have the opportunity to increase this year.

The consumer goods industry sector is divided into five sub-sectors, namely food and beverages, cigarettes, pharmaceuticals, cosmetics, and household appliances. This research is to empirically examine the effect of profitability, ownership structure on company value with dividend policy as an intervening variable for companies included in the consumer goods industry listed on the Indonesia Stock Exchange in the period 2011 to 2016. This study aims to examine and obtain empirical evidence of the effect of profitability and ownership structure on firm value with dividend policy as an intervening variable.

\section{Conceptual Framework}

The conceptual framework illustrates the effect of Profitability (X1), and Ownership Structure (X2) on Corporate Value (Y1) through the intervening variable Dividend Policy (Y2). Following is the conceptual framework of this study:

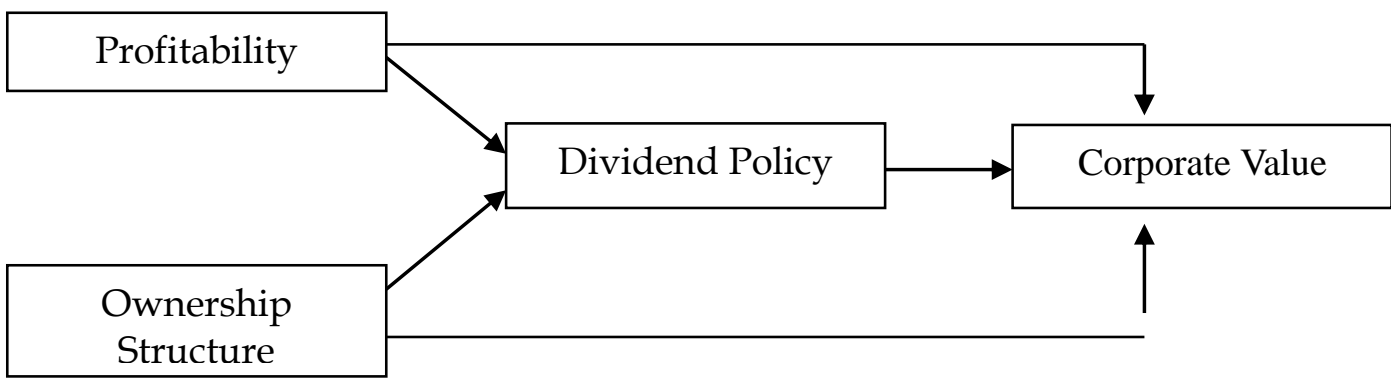

Figure 1 Conceptual Framework 


\section{Hypothesis}

The Effect of Profitability on Dividend Policy

Profitability shows the ability of a company to generate profits in an accounting period. According to Brigham and Houston (2001) revealed that companies that are able to generate high profits are said to be able to pay high dividends. According to Mahendra (2011) states that profitability is one of the factors that influence dividend policy. Nurhayati (2013) research and Lestari and Sulistyawati (2017) obtained empirical evidence of profitability having a positive influence on dividend policy. The higher the value of profitability, the dividends given can increase. However, different from Nofrita (2013), Rais and Santoso (2017), Deviana and Fitria (2017) which prove that profitability does not have a significant effect on dividend policy. From the several studies above, the following hypotheses can be formulated:

H1: Profitability has a positive effect on dividend policy.

\section{The Effect of Ownership Structure on Dividend Policy}

According to Jensen and Meckling (1976), it is stated that the higher the ownership structure is controlled by management or the smaller that is controlled by outside management, the lesser agency conflict, because the harmony between management's interests and the owner is mostly management itself. In such a case, the smaller the dependence on dividends as a monitoring mechanism. In addition, the presence of largeblock shareholding, such as institutional shareholding, which has a more effective monitoring capacity than the small and scattered shareholders, will also reduce the role of dividends as mechanism monitoring (Easterbrook, 1984). Research by Rais and Santoso (2017) shows that managerial ownership has no effect on dividend policy. In contrast to the results of the Cisilia and Amanah (2017) research that prove managerial ownership influences dividend policy. Based on some of these studies hypotheses can be formulated as follows:

H2: Ownership structure has a positive effect on dividend policy.

\section{The Effect of Profitability on Company Values}

The company's ability to earn profits (profit) is realized in profitability ratios. Companies with high profitability indicate the higher the value of the company. Putra Research (2014), Muvidha and Suryono (2017), Windasari and Riharjo (2017), and Rahmawati and Amboningtyas (2017) prove empirically that profitability has a significant positive effect on firm value. Safitri et al. (2014) stated that profitability proved to have a significant and positive influence on firm value. This shows that companies with high profitability will be followed by a high value of the company. In the research of Mahendra (2011) the profitability ratio is proxied using Return On Equity. ROE can determine the company's ability to generate profits through its own capital. This study uses measurement of profitability in the form of Return on Equity (ROE). The higher the profit generated, the higher the share of dividends distributed. High profits and dividends can affect the value of the company that also increases. From the several studies above, the following hypotheses can be formulated:

H3: Profitability has a positive effect on company value.

\section{The Effect of Ownership Structure on Company Values}

Jensen and Meckling (1976) state that ownership structure can influence agency conflict. Companies that have high managerial ownership can minimize the agency costs that arise. A small agency cost can increase the value of the company. Hardiningsih (2009) divides ownership structure into two namely managerial ownership and institutional ownership. The results of the study are the influence of managerial ownership and institutional ownership on firm value. Research by Kim et al. (2005) state that ownership structure affects the value of the 
company. Sofyaningsih and Hardiningsih (2011) prove that there is a significant and positive influence of ownership structure on firm value. Whereas Muvidha and Suryono (2017) show the results of the absence of influence of managerial ownership on firm value. From the several studies above, the following hypotheses can be formulated:

H4: Ownership structure has a positive effect on firm value.

The Effect of Dividend Policy on Company Values

High dividend distribution is one positive signal for investors for investors to invest their money. High dividends can increase investor expectations so that it can indirectly increase stock prices. The stock price is a reflection of the value of the company. In the theory of "The Bird in The Hand, this theory agrees with Gordon and Lintner (1992) who argue that investors feel more secure to obtain income in the form of dividend payment rather than waiting for capital gains.

The results of the study by Hardiningsih (2009) state that dividend policy has a significant positive effect on firm value. Wijaya's research (2010) also empirically proves that dividend policy has a positive and significant effect on firm value. Kim et al. (2005) stated that dividend policy has an influence on firm value. Different results of the study are explained by Rakhimsyah and Gunawan (2011) and Deviana and Fitria (2017) that dividend policy has a negative effect on firm value. Nurhayati's research (2013) shows that dividend policy does not have a significant effect on firm value. Rahmawati and Amboningtyas (2017) and Mutmainnah et al. (2019) prove that dividend policy has a significant positive effect on firm value. Based on some of the above studies, the following hypotheses can be formulated:

H5: Dividend policy has a positive effect on company value.

The Effect of Profitability on Company Values with Dividend Policy as Intervening Variables

According to Brigham and Houston (2001: 24) revealed that companies that are able to generate high profits are able to pay high dividends as well. Profitability is one of the factors that influence dividend policy. Profitability is one indicator that can determine the value of a company. Rahmawati and Amboningtyas (2017) research shows that dividend policy is proven to be an intervening variable between profitability and firm value, meaning that the higher dividends distributed will affect the company's profitability, the company's value will also increase. From the several studies above, the following hypotheses can be formulated:

H6: Profitability has a positive effect on company value with dividend policy as an intervening variable.

The Effect of Ownership Structure on Company Values with Dividend Policy as Intervening Variables

Jensen and Meckling (1976) explained that the higher the ownership structure controlled by management or the smaller the control by outside parties, the lesser agency conflict, because the more aligned between management interests and the interests of the owners, most of whom are management themselves. Sturtur ownership also underlies the company's dividend distribution policy. Most outstanding shares owned by the public tend to want a high dividend distribution as a return on investment. From the several studies above, the following hypotheses can be formulated:

H7: Ownership structure has a positive effect on company value with dividend policy as an intervening variable. 


\section{Research Methods}

This research is included in the type of quantitative descriptive research with explanatory approach. Explanatory research aims to analyze the relationship or causal influence of one variable to another through testing hypotheses. Exogenous variables used are profitability and ownership structure. Endogenous variable is the value of the company. And the intervening variable is dividend policy.

The data source used in this study is secondary data. Secondary data is obtained in the form of notes, as well as documents related to the company's financial and non-financial information listed in the financial statements and annual reports. Data is obtained from the Indonesia Stock Exchange with the website www.idx.co.id.

Data collection in this research is carried out by downloading financial statements and company annual reports through the Indonesia Stock Exchange website and the entity concerned.

\section{Population and Samples}

The population in this study are companies incorporated in the consumer goods industry sector that are listed on the Indonesia Stock Exchange in the period 2011 to 2016. The sample selection in this study used purposive sampling technique with the following criteria: (1) The consumer goods industry sector companies listed on the Indonesia Stock Exchange in the period 2011 to 2016. (2) The company publishes financial statements and annual reports for the period ending 31 December. (3) The company does not carry out mergers, acquisitions and business types. Based on these criteria, a sample of 189 companies was obtained. Table 1 shows the sample companies.

Table 1 Data Samples

\begin{tabular}{lc}
\hline Years & Total \\
\hline 2011 & 30 \\
2012 & 30 \\
2013 & 32 \\
2014 & 32 \\
2015 & 32 \\
2016 & 33 \\
\hline
\end{tabular}

\section{Analysis and Discussion}

\section{Overview of Research Objects}

The research data comes from annual reports and financial reports from companies incorporated in the consumer goods industry sector which are listed on the Indonesia Stock Exchange from 2011 to 2016. Based on SPSS output, the value of standardized beta profitability in model 1 is 0.411 and significance is 0.000 , which means that profitability has an effect on dividend policy. The standardized beta value of managerial ownership in model 1 is -0.113 and significance is 0.089 which means that managerial ownership has an effect on dividend policy. The standardized beta value of 0.536 profitability coefficient with a significance of 0,000 and a dividend policy of 0.249 with a significance of 0,000 in model 2 shows that profitability and dividend policy affect the value of the company. The standardized beta value of managerial ownership coefficient -0.050 with a significance of 0.358 in model 2 shows managerial ownership does not affect the value of the company. 


\section{Discussion}

\section{The Effect of Profitability on Dividend Policy}

The results of the analysis using SPSS show that profitability affects dividend policy. The level of significance obtained is 0,000 , smaller than the significance level of $1 \%$. While the value of standardized beta profitability on dividend policy is 0.411 , it can be interpreted that if there is an increase in profitability of 1 , the dividend policy will increase by 0.411 . This result supports hypothesis 1 which states that profitability has a positive effect on dividend policy received.

The results of this study support the results of research from Nurhayati (2013), Rahmawati and Amboningtyas (2017), and Lestari and Sulistyawati (2017) who argue that profitability has a significant positive effect on dividend policy. According to Brigham and Houston (2001) profitability is one of the main determinant factors in consideration of dividend payments. The higher profitability shows the better management in running the company's operations. The results of this study indicate that the higher the value of profitability, the higher the dividend distribution.

\section{The Effect of Ownership Structure on Dividend Policy}

The results of the analysis using SPSS show that the ownership structure influences dividend policy. The level of significance obtained is 0.089 , smaller than the significance level of $10 \%$. While the standardized beta value is -0.113 , it can be interpreted that if there is an increase in ownership structure of 1 , the value of the company will decrease by 0.113 . This result supports hypothesis 2 which states that ownership structure influences dividend policy received.

The results of this study are in line with agency cost models (Jensen and Meckling, 1976) which say that the effectiveness of dividends as a means of monitoring depends on other monitoring facilities such as ownership structures. The results of this study are in line with the research of Cisilia and Amanah (2017) and Sumartha (2016) which prove managerial ownership has an influence on dividend policy. Wijayanto and Putri (2019) shows that managerial ownership simultaneously significantly influence dividend policy.

\section{The Effect of Profitability on Company Values}

The results of the analysis using SPSS show that profitability affects the value of the company. The level of significance obtained is 0,000 , smaller than the significance level of $1 \%$. While the value of standardized beta profitability on company value is 0.536 . It can be interpreted that if there is an increase in profitability of 1 , the value of the company will increase by 0.536 . This result supports hypothesis 3 which states that profitability has a positive effect on accepted firm value.

This study supports the results of Safitri et al. (2014) and Mahendra (2011), Nofrita (2013), Windasari and Riharjo (2017) which state that Profitability has a significant and positive influence on firm value. This shows that a company that has a high value of profitability will be followed by a high value of the company. The reason is because the increase in the profitability of the company will affect investors' investment decisions. From the viewpoint of investors, companies that are able to generate high profits can maximize shareholder wealth. Of course this will have an impact on the increasing value of the company.

\section{The Effect of Ownership Structure on Company Values}

The results of the analysis using SPSS show that the ownership structure does not have a 
significant effect on firm value. The level of significance obtained is 0.358 , greater than the significance level of $10 \%(0.10)$. The standardized beta value is -0.050 , it can be interpreted that if there is an increase in ownership structure of 1 , the value of the company will decrease by 0.050. This result does not support hypothesis 4 which states that the ownership structure has a positive effect on the value of the company rejected.

These results support the results of the research from Hidayah (2015) which states that the ownership structure does not significantly influence the value of the company. This study also supports research from Hardiningsih (2009) which states that managerial ownership does not significantly influence company value. The results of this study are not consistent with agency theory proposed by Jensen and Meckling (1976) which states that with company stock ownership by management or managerial ownership, it will result in managers feeling directly the benefits of decisions taken and also if there are losses that arise due to the wrong decision, the manager can feel the consequences.

\section{The Effect of Dividend Policy on Company Values}

The results of the analysis using SPSS show that dividend policy affects the value of the company. The level of significance obtained is 0,000 , smaller than the significance level of $1 \%$. While the standardized beta value of dividend policy on company value is 0.249 . It can be interpreted that if there is an increase in dividend policy of 1 , the value of the company will increase by 0.249 . This result supports hypothesis 5 which states that dividend policy has a positive effect on accepted firm value.

The results of this study support the results of research from Harahap and Wardhani (2013), Wijaya (2010), Nofrita (2013), Mahendra (2011), and Mutmainnah et al. (2019) which states that dividend policy has a significant effect on firm value. The results of this study are in accorandce with the agency theory (Jensen and Meckling, 1976) which states that a small agency cost can increase company value, the Agency cost caused by the agency conflict can be minimized through a bonding mechanism consisting of ownership structure, debt structure and dividend structure.

\section{Conclusion}

This study aims to examine the value of the company that is influenced by profitability, ownership structure and dividend policy. This study used 189 samples from companies incorporated in the consumer goods industry sector on the Indonesia Stock Exchange with the study period from 2011-2016.

The results of this study indicate that profitability has an influence on the Dividend Policy with a significance of 0,000 ( $\mathrm{H} 1$ accepted). Companies that have the ability to generate profits will cause companies to increase dividend policies. The ownership structure has an influence on the Dividend Policy with a significance of 0.089 ( $\mathrm{H} 2$ accepted). The results of the study of the effect of profitability on corporate value (H3 is accepted). The value of the company will be better if the company is able to generate high profits. The dividend policy has an influence on the value of the company with a significance of 0.010 (H4 accepted). The dividend policy carried out by the company will get a response from the shareholders. Therefore, the existence of a dividend policy will have an impact on increasing the value of the company.

The ownership structure has no effect on firm value with a significance of 0.358 (H5 rejected). High managerial ownership causes the performance of management as the manager and shareholders to be less than optimal, this should continue to be increased to add value to the company. The results of the study of the effect of profitability on firm value through dividend 
policy obtained evidence that dividend policy was able to mediate the effect of profitability on firm value (H6 accepted). This is supported by standardized beta values. Companies that have the ability to generate profits will add value to the company, and this will be better if through a good corporate dividend policy. The results of the study of the influence of ownership structure on the value of the Company through dividend policy obtained evidence that dividend policy is not able to mediate the influence of ownership structure on firm value ( $\mathrm{H} 7$ is rejected). This is because the ownership structure has proven to have no influence on the value of the company. Companies with high managerial ownership do not necessarily provide a level of trust for shareholders to want to invest so that it does not affect the value of the company.

For further research can use other types of companies as a sample of the company. Company value in this study is able to be influenced by profitability, dividend policy, and ownership structure so that for future research other variables can be used. This study only uses PBV measurements for company value variables, for further research is expected to use other measurements.

\section{References}

Brigham, E. F. and J. F. Houston. Financial Management: Theory and Practice. Edisi 8. Penerbit Erlangga. Jakarta. 2001.

Cisilia, A. and L. Amanah. Pengaruh Profitabilitas, Leverage, Cash Position, Growth, dan Kepemilikan Manajerial Terhadap Nilai Perusahaan. Jurnal Ilmu and Riset Akuntansi 6 (3). 2017.

Deviana, N. and A. Fitria. Pengaruh Profitabilitas and Keputusan Investasi Terhadap Nilai Perusahaan Melalui Kebijakan Dividen. Jurnal Ilmu and Riset Akuntansi 6 (3). 2017.

Dewi, L.S. and N. Abundanti. Pengaruh Profitabilitas, Likuiditas, Kepemilikan Institusional dan Kepemilikan Manajerial Terhadap Nilai Perusahaan. E-Jurnal Manajemen 8 (10). 2019.

Easterbrook, F. H. Two Agency - Cost Explanations of Dividens. The American Economic Review 74 (4): 650-659. 1984.

Fama, E. F. and K. R. French. Taxes, Financing Decisions, and Firm Value. Journal of Finance 53 (3): 819-843. 1998.

Fuerst, O. and S. Kang. Corporate Governance, Expected Operating Performance, and Pricing. Working Papers. Yale School of Management. United States. 2000.

Hakim, L and D. Priantinah. Faktor-Faktor yang Mempengaruhi Nilai Perusahaan pada Perusahaan Manufaktur yang Terdaftar di Bursa Efek Indonesia. Profita Kajian Ilmu Akuntansi 6 (8). 2018.

Harahap, L. and R. Wardhani. Analisis Komprehensif Pengaruh Family Ownership, Masalah Keagenan, Kebijakan Dividen, Kebijakan Hutang, Corporate Governance And Opportunity Growth Terhadap Nilai Perusahaan. Simposium Nasional Akuntansi XV. Balikpapan. 2013.

Hardiningsih, P. Determinan Nilai Perusahaan. Jurnal Akuntansi Indonesia 5 (2): 231-250. 2009.

Herlambang, A. Pengaruh Struktur Kepemilikan Terhadap Kebijakan Dividen. Skripsi. Universitas Airlangga. Surabaya. 2016.

Hidayah, N. Pengaruh Investment Opportunity Set (IOS) and Kepemilikan Manajerial Terhadap Nilai Perusahaan pada Perusahaan Property and Real Estate di Bursa Efek Indonesia. Jurnal Akuntansi Universitas Tarumanegara. 19 (3). 2015.

Jensen, M. C. and W. H. Meckling. Theory Of The Firm: Managerial Behaviour, Agency Cost, and Ownership Structure. Journal of Financial Economics 3: 305-360. 1976.

Kim, Y. H., J. C. Rhim, and J. G. Kang. Agency Costs And Corporate Financial Policies: A 
Simultaneous Equations Approach. Journal of Business and Economics Research 3. 2005.

Lestari, E. and A. I. Sulistyawati. Kebijakan Dividen pada Indeks Saham LQ45 di Bursa Efek Indonesia. Jurnal Akuntansi Indonesia 6 (2): 113-130. 2017.

Mahendra, A. Pengaruh Kinerja Keuangan Terhadap Nilai Perusahaan dengan Kebijakan Dividen Sebagai Variabel Moderating pada Perusahaan Manufaktur di Bursa Efek Indonesia. Tesis. Program Pasca Sarjana Universitas Udayana. Denpasar. 2011.

Mardiyati, U., G. N. Ahmad., and R. Putri. Pengaruh Kebijakan Dividen, Kebijakan Hutang, dan Profitabilitas Terhadap Nilai Perusahaan Manufaktur yang Terdaftar di Bursa Efek Indonesia Periode 2005-2010. Jurnal Riset Manajemen Sains Indonesia (JRMSI) 3 (1) : 1-17. 2012.

Mutmainnah, Z. Puspitaningtyas, and Y. Puspita. Pengaruh Kebijakan Dividen, Keputusan Investasi, Ukuran Perusahaan dan Kepemilikan Manajerial Terhadap Nilai Perusahaan. Buletin Studi Ekonomi 24 (1). 2019.

Muvidha, N. I. and B. Suryono. Pengaruh Struktur Kepemilikan, Keputusan Penandaan, Profitabilitas, dan Ukuran Perusahaan Terhadap Nilai Perusahaan. Jurnal Ilmu and Riset Akuntansi 6 (5). 2017.

Nofrita, R. Pengaruh Profitabilitas Terhadap Nilai Perusahaan Dengan Kebijakan Deviden Sebagai Variabel Intervening (Studi Empiris pada Perusahaan Manufaktur Yang Terdaftar di BEI). Skripsi. Program Sarjana Universitas Negeri Padang. Padang. 2013.

Nurhayati, M. Profitabilitas, Likuiditas, and Ukuran Perusahaan Pengaruhnya Terhadap Kebijakan Dividen and Nilai Perusahaan Sektor Non Jasa. Jurnal Keuangan and Bisnis 5 (2). 2013.

Putra, R. A. Pengaruh Profitabilitas, Struktur Modal, Nilai Perusahaan and Likuiditas Terhadap Nilai Perusahaan (Studi pada Perusahaan Asuransi di Bursa Efek Indonesia Tahun 2010-2012). Artikel. Universitas Brawijaya. Malang. 2014.

Rahmawati, N. and D. Amboningtyas. The Influence of Profitability and Leverage to Company Values With Dividend Policies as Intervening Variabel (In LQ45 Company Listed in BEI Period of 2012-2016. Jurnal. Universitas Pandanaran. Semarang. 2017.

Rais, B. N. and H. F. Santoso. Pengaruh Kepemilikan Manajerial, Kepemilikan Institusional, Profitabilitas, and Ukuran Perusahaan Terhadap Kebijakan Dividen. Jurnal Ilmiah Manajemen Bisnis 17 (2): 111-124. 2017.

Rakhimsyah, L. A. and B. Gunawan. Pengaruh Keputusan Investasi, Keputusan Penandaan, Kebijakan Dividen and Tingkat Suku Bunga Terhadap Nilai Perusahaan. Jurnal Investasi 7 (1): 31-45. 2011.

Safitri, O. N., S. R. Handayani, and N. F. Nuzula. The Influence Of Capital Structure And Profitability On Firm Value (A Study in Retail Companies Listed in Indonesia Stock Exchange 2010-2013 period). Jurnal Administrasi Bisnis 13 (2). 2014.

Sartono, A. Manajemen Keuangan: Teori and Aplikasi. BPFE. Yogyakarta. 2010.

Sofyaningsih, S. and P. Hardiningsih. Struktur Kepemilikan, Kebijakan Dividen, Kebijakan Utang and Nilai Perusahaan. Dinamika Keuangan and Perbankan 3 (1): 68-87. 2011.

Soliha, E. and Taswan. Pengaruh Kebijakan Hutang Terhadap Nilai Perusahaan Serta Beberapa Faktor yang Mempengaruhinya. Jurnal Ekonomi and Bisnis 1: 1-18. 2002.

Sondang, P. Siagian. Manajemen Strategik. PT Bumi Asmara. Jakarta. 2005.

Sumartha, E. Pengaruh Struktur Kepemilikan Terhadap Kebijakan Dividen pada Perusahaan Manufaktur. Jurnal Economia 12 (2). 2016.

Sukirni, D. Kepemilikan Manajerial, Kepemilikan Institusional, Kebijakan Dividen, dan Kebijakan Hutang Analisis Terhadap Nilai Perusahaan. Accounting Analysis Journal 1 (2). 
2012.

Wijaya, L. R. P. Implikasi Keputusan Investasi, Penandaan, and Dividen Terhadap Nilai Perusahaan. Tesis. Program Pasca Sarjana Universitas Sebelas Maret. Surakarta. 2010.

Wijayanto, E. and A. N. Putri. Analisis Pengaruh Rasio Likuiditas, Rasio Leverage, Rasio Profitabilitas, dan Kepemilikan Manajerial Terhadap Kebijakan Dividen. Jurnal Aktual Akuntansi Keuangan Bisnis Terapan (Akun Bisnis) 1 (2). 2018.

Windasari, O. and I. B. Riharjo. Pengaruh Good Corporate Governance, Profitabilitas, and Corporate Social Responsibility Terhadap Nilai Perusahan. Jurnal Ilmu and Riset Akuntansi 6 (10). 2017.

Copyright (c) 2020 Ulfah Setia Iswara, Teguh Gunawan Setyabudi 